\title{
Does ecotourism in a Mangrove area at Klong Kone, Thailand, conform to sustainable tourism? A case study using SWOT and DPSIR
}

\author{
Kanokporn Swangjang ${ }^{1}$ (D) Phitwalan Kornpiphat $^{1}$
}

Received: 12 October 2019 / Accepted: 27 February 2021 / Published online: 16 March 2021

(c) The Author(s), under exclusive licence to Springer Nature B.V. 2021

\begin{abstract}
This study aimed to assess ecotourism in a mangrove area and whether it conformed with sustainable tourism. We were interested in exploring the demand for natural resources and the supply of areas for ecotourism. To achieve this, we integrated a SWOT (strengths, weaknesses, opportunities, and threats) analysis with the DPSIR (driving forces, pressures, states, impacts, and responses) framework, based on questionnaire interviews with three target groups (tourists, homestay operators, and community residents), plus in-depth interviews with local scholars and officers of administrative organizations. Supplementary data recorded included the physical characteristics of local homestays and houses. The results were analyzed statistically and the ecotourism carrying capacity of the area was assessed, based on the SWOT analysis. Internal factors included key strengths, e.g., the income associated with nature-supporting tourism, and key weaknesses, e.g., local stakeholders' awareness and understanding of ecological mechanisms. External factors included opportunities arising from tourism policies and public relations and threats from town and urban planning and pollution from nearby areas. The DPSIR framework was used to rank the scores of each DPSIR dimension, with the responses identifying DPSIR indicators prioritized. Finally, a conceptual DPSIR model of ecotourism, which illustrated the ecotourism lifecycle, was developed.
\end{abstract}

Keywords Ecotourism - Sustainable tourism $\cdot$ Mangrove area $\cdot$ Carrying capacity $\cdot$ SWOT . DPSIR

Kanokporn Swangjang swangjang_k@su.ac.th

Phitwalan Kornpiphat water_ph6.25@hotmail.com

1 Department of Environmental Science, Faculty of Science, Silpakorn University, Nakorn Pathom 73000, Thailand 


\section{Introduction}

Ecotourism comprises eco-friendly activities. It is a form of sustainable tourism that enables tourists to travel to natural areas while taking into consideration the needs of local communities and the benefits to local stakeholders of conserving cultural and natural areas (Hirotsune, 2011; Ly \& Bauer, 2014). Ecotourism can create both positive and negative impacts on areas being visited and where recreational activities take place (Ahmad et al., 2018; Gössling, 2002). The impacts associated with ecotourism can be divided into two main categories: impacts from the construction of tourism-supporting facilities and impacts from visiting tourists (May, 1991). These are the pressures an ecosystem can tolerate in relation to changes in visitor numbers or tourism activities, while allowing the ecological effects to remain within acceptable levels (Oh et al., 2002).

Ecotourism usually takes place in areas of natural richness. Mangrove forests are a good example of such areas. Mangrove areas represent both an attractive ecotourism site and a sensitive ecosystem. Mangroves provide important ecosystem services, e.g., shelter for economically important aquatic larvae, a buffer against coastal erosion, and a major carbon sink. In the tropics, mangrove forests play an important role in people's ways of life (Teka et al., 2019). Hence, there may be conflicts between sustaining a good environment and the economic benefits of mangroves; activities within mangrove areas can affect their ecosystem services. Ecotourism is a popular activity in mangrove areas but poses a high risk of pollution (de Groot et al., 2010). Ecotourism activities vary, and their effects among different stakeholders can be complicated (Do et al., 2015). An awareness of impacts in mangrove areas should relate to both local and macro-levels, especially in relation to climate change and the hidden impacts of ocean acidification.

If local communities are supportive of ecotourism, factors related to likely environmental impacts on sustainable ecotourism in the area should be considered. It is necessary to assess the carrying capacity of tourist areas and measure the limits of both natural resources and human-made resources related to tourism activities (Saveriades, 2000). The specific conditions in each area should be studied to ensure the supply and demand on an ecosystem from ecotourism activities are balanced. Here, we describe an assessment of a mangrove ecotourism area in Thailand, and whether it conforms to sustainable tourism principles.

\section{Literature review}

A major question for this research was whether ecotourism in mangrove areas conforms to sustainable tourism. Sustainable tourism is strategically planned to achieve the goals of sustainability; this includes environmental dimensions in addition to social and economic factors and the manifestation of these effects over the long term (Atun et al., 2019). Sustainable tourism should ensure the optimal use of environmental resources, respect the sociocultural characteristics of local communities, provide an equitable distribution of benefits among stakeholders, and protect the interests of future generations (Jaafar and Maideen, 2012; Kiper, 2013; Kisi, 2019).

According to Zareba (2017), the interlinked elements of ecotourism include: (1) natural areas and cultural resources; (2) environmental and ecological sustainability; (3) provision of environmental and ecological education to stakeholders; (4) participation of and benefits 
to local economies; and (5) residents' satisfaction with ecotourism. An assessment of specific ecotourism sites is necessary for the development of management strategies (Ross \& Wall, 1999). Southeast Asia possesses many attractive natural resources; therefore, ecotourism is a major contributing factor in the socioeconomic development of this region. However, it can be difficult to balance the supply and demand of ecosystem services for ecotourism activities in areas where the ecotourism is operated solely by local communities. Furthermore, each ASEAN country has a unique and complex culture, and this can affect the attitude of local communities (Boyle, 1998). The perceptions and cooperation of local communities are very important (Arkwright \& Kaomaneng, 2018; Pornprasit \& Rurkkhum, 2017; Yacob et al., 2013). For example, the relationships among people, resources, and tourism in North Sulawesi, Indonesia, provide the mutual benefits necessary for successful ecotourism (Ross \& Wall, 1999). Interestingly, the social dimension of gender was seen to be a key category for community-based, sustainable ecotourism in the Cardamom Mountains in Cambodia (Reimer \& Walter, 2013).

In terms of mangrove areas, if ecotourism is to conform to sustainable tourism standards, three pillars should be maintained: economic, social, and environmental sustainability (Niñerola et al., 2019). Many studies of the social dimension have focused on community empowerment and participation to support the management of ecotourism in mangrove areas. These have included using Arnstein's ladder of citizen participation to identify the level of community participation in the development of ecotourism in Surabaya, Indonesia (Idajati et al., 2016); a study of how to manage community empowerment for ecotourism in mangrove forests in Bantu Regency, Indonesia (Hastuti \& Yuliati, 2017); an analysis of the inherent social capital in Muara Baimbai, Indonesia (Situmorang, 2018); and the development of a model of ecotourism management and mangrove forest conservation through community participation in Satun, in the south of Thailand (Treephan et al., 2019). Socioeconomic dimensions have sometimes been explored together. For example, Fattah et al., (2020) determined sustainable conditions for mangrove ecotourism by conducting a cost-benefit analysis to assess the ecological and cultural costs and benefits of such tourism. For the environmental dimension, the importance of mangrove forest characteristics and the suitability of these areas for ecotourism were highlighted in a study by Hakim et al., (2017), carried out in East Java, and another by Rahmila and Halim (2018) at Mangunharjo mangrove village, Indonesia. A study of the seasonal climatic conditions as environmental variables that affected the patterns of activity of Asian water monitors (Varanus salvator) was conducted by Rahman et al., (2017) in a mangrove ecotourism spot. These studies provide important insights into the interconnectedness of the sustainability dimension of ecotourism in mangrove areas.

Ecotourism will not be sustainable unless it is economically viable, environmentally appropriate, and sociocultural considerations are taken into account. Different areas have different features that can affect ecotourism activities and management, so alternative approaches should be used to assess ecotourism potential (Yan et al., 2017). Various methods can be used to plan and manage ecotourism (Hoang et al., 2018; Sahani, 2019). In this study, a SWOT (strengths, weaknesses, opportunities, and threats) analysis and the DPSIR (driving forces, pressures, states, impacts, and responses) framework were adopted to perform an assessment of a mangrove ecotourism area. A combination of SWOT and DPSIR can produce appropriate results (Skrondas \& Karavitis, 2015) and provide valuable insights into current circumstances, including both internal and external factors; this is crucial for assessing cause and effect relationships for particular conditions in a given area.

DPSIR is an essential tool for supporting the decision-making process (Tscherning et al., 2012). It can be used to address complex environmental conditions and determine 
alternative management approaches appropriate to a particular area. Vidal-Abarca et al., (2014) used the DPSIR framework to explore complex interlinkages between fluvial and social ecosystems in Spain. Bradley and Yee (2015) presented a case study that used DPSIR to support complex environmental decisions around ecological issues, tourism and recreation, and ecological health. The DPSIR framework can identify cause and effect relationships and facilitate the linkage of scientific findings with real-world issues (Tscherning et al., 2012).

The DPSIR framework can be applied at different levels. For example, Glyptou et al., (2012) explored cause-effect relationships of the supply and demand of tourism activities, based on tourist numbers and both direct and indirect consequences; they subsequently established a DPSIR framework in accordance with policy guidelines to provide an assessment of tourism sustainability in Mediterranean countries. Tsai et al., (2009) applied DPSIR at a macro-level to investigate transboundary impacts in Europe and then made recommendations for environmental management.

Although DPSIR can contribute the core approach to a decision-making process, it must often be supplemented with other tools when conducting analyses of complex systems (Chuang et al., 2018; Mimidis et al., 2017). The scope of DPSIR can be expanded and combined with other tools to help solve environmental problems and generate new knowledge. A SWOT analysis is one of the tools that can be integrated with DPSIR and adapted to identify critical factors. In a SWOT analysis, factors in a given study are categorized (Battisti et al., 2016; Kazemi et al., 2018) as being internal (strengths/weaknesses) or external (opportunities/threats). The advantage of a SWOT analysis is that it can be used to evaluate local tourism resources (Yan et al., 2017), based on both current and future constraints. Previous examples have included decision-making support to plan the cultivation of shrubs and trees in urban landscapes in Iran (Kazemi et al., 2018); the identification of internal and external factors that influence mangrove ecotourism management at Kakaralamo Island, Indonesia (Arkwright \& Kaomaneng, 2018); and assessing the capacity of non-governmental organizations (NGOs) engaged in ecotourism in China (Zhuang et al., 2011). A limitation of SWOT analyses is that they may provide an incomplete list of internal and external factors (Kazemi et al., 2018); under these circumstances, other indicators related to these factors should be determined.

The output of any assessment is useless if policy and managerial implications are ignored. Knowledge of relationships between the environment and tourism activities is necessary to develop appropriate policy, planning, and practice (Kiper, 2013). Good management of ecotourism includes protection of ecological and cultural contexts (Hitchner et al., 2009), enhancement of tourism products (Jaafar \& Maideen, 2012; Yacob et al., 2013), promotion of local people's knowledge and perceptions (Hearne \& Santos, 2005; Satyanarayana et al 2012), improved income and welfare for the local community (Blersch \& Kangas, 2013; Koens et al., 2009; Pornprasit \& Rurkkhum, 2017), and flexible, integrated plans to cover policy at both regional and local levels (Arkwright \& Kaomaneng, 2018). These implications depend on decisions made by individuals. Examples of tourism management implications include a focus on both the tangible and intangible benefits provided to tourists, with an emphasis on the management and planning of ecological resources (Chiu et al., 2014). This must be based on the identification of the central characteristics of sustainable service innovation for the hospitality industry (Horng et al., 2016), and theoretical, managerial implications using criteria set to measure ecotourism development in practice (Tseng et al., 2019). Some areas that have been recognized by UNESCO or other international organizations, such as Kilim Geopark (Yacob et al., 2013) or the Kelabit Highlands in Malaysia and the Kerayan Highlands in Indonesia (Hitchner 
et al., 2009), have official strategies for the planning of ecotourism activities. Managers of mangrove ecotourism may wish to consider an analysis of economic aspects (Fattah et al., 2020) or the linkage between socioeconomic and sociocultural conditions (Purba et al., 2018). The use of mangrove resources, knowledge of mangroves, and perceptions of ecosystem changes based on a socio-ecological assessment was proposed by Satyanarayana et al., (2012) for the management of sustainable ecotourism in Gambia.

The prior studies outlined above are valuable; however, based on our literature review, most of the research into ecotourism in mangrove areas was conducted in tropical region. Some gaps in the interconnectedness between stakeholders and the supply and demand of mangrove areas where ecotourism takes place have been evident. Without the required assessment of ecotourism in mangrove areas, there is a possibility of demands on resources outstripping supply. These findings led to this study, which aimed to assess whether ecotourism activities in mangrove areas are compatible with sustainable tourism. An interdisciplinary approach was adopted, using a combination of SWOT analysis and the DPSIR framework, and the indicators and other related factors that affect supply and demand in the study area were investigated. A conceptual DPSIR framework for the ecotourism lifecycle was used to determine whether ecotourism activities and their correct management could control the level of activities so that they remained within the carrying capacity of the area. Based on these objectives, this work contributes to the current knowledge gap in the literature, as follows. First, this study used a framework of causes and effects that were concerned with the limit of the carrying capacity of a sensitive area. Second, a survey of all stakeholder groups in the area was carried out to determine the actual demand on resources in the area. Third, the assessment incorporated relevant stakeholders together with the social, environmental, and economic dimensions of sustainable tourism in mangrove areas. Finally, the integration of DPSIR and the SWOT analysis resulting from the novel insights obtained by this study was explored, together with the identification of possible inputs for policy and management strategies.

\section{Materials and methods}

Researchers' scientific contributions to sustainable development can be classified into three types: (1) providing an understanding of certain phenomena, (2) outlining sustainable resource-use patterns, and (3) determining selected parameters in specific contexts (Wuelser \& Pohl, 2016). The scientific contribution of the present study can be considered to be type 1 , as the work aimed to clarify ecotourism activities in a mangrove area and whether these activities are sustainable. The understanding of how stakeholders engaged in ecotourism activities was illustrated by their behavior patterns and could be seen as a causeand-effect relationship. The factors influencing the framing of the research were derived from evidence collected from the area. A step-by-step overview of the research methods is shown in Fig. 1. First, the research target was set. A literature review and survey were the main components of the research design. Data were systematically collected and analyzed. Target groups of stakeholders were identified, the stakeholder questionnaires were designed, questions were developed for the in-depth interviews with local scholars and officers from the local administration, and the survey was planned. Data analysis was conducted using both qualitative and quantitative approaches. The main theoretical basis used to analyze the sustainability of ecotourism activities involved a combination of a SWOT analysis and the DPSIR framework. 


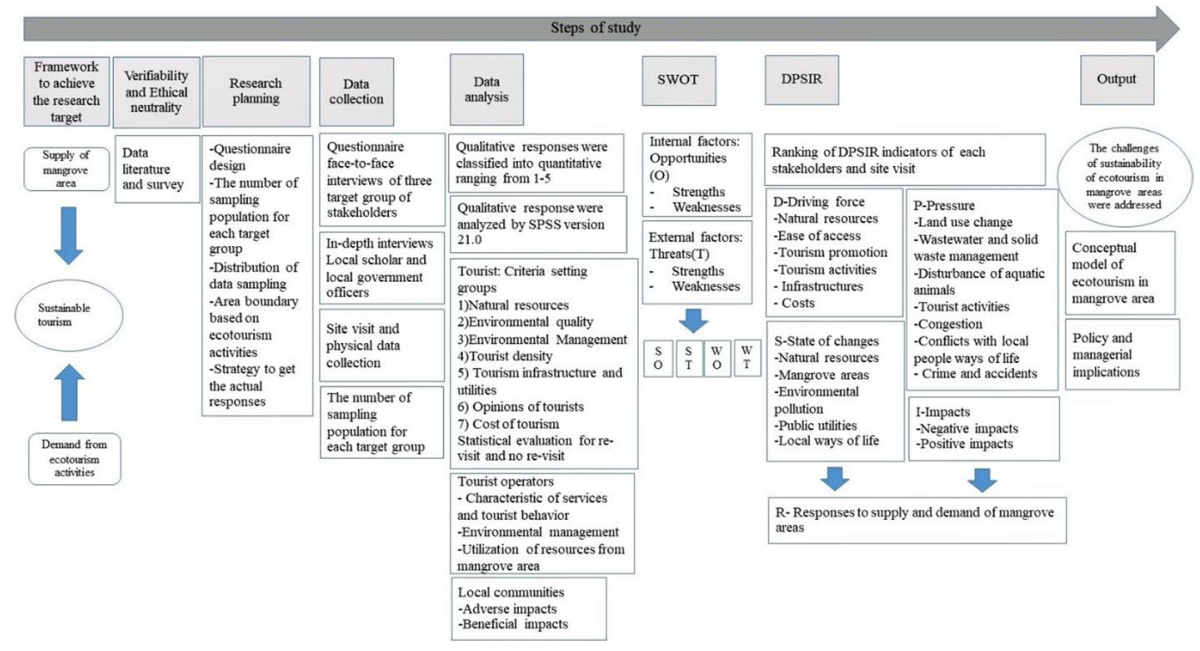

Fig. 1 Research framework

Innovations to facilitate processes for enhancing environmentally sustainable tourism were inspired and affected by a range of internal and external factors, which were assessed by the SWOT analysis. These issues were addressed by interviewing stakeholders in ecotourism activities, members of the local community, local scholars, and officers from subdistrict administrative organizations, as well as making observations during site visits and performing a literature review. Integrating the DPSIR and SWOT analyses provided an innovative approach to address the supply and demand of ecosystem services among stakeholders engaged in ecotourism in mangrove areas.

To obtain a better understanding of the role played both by the general public and by stakeholders, the indicators of ecotourism activity-relevant stakeholders engaged in were identified, and face-to-face questionnaire interviews were conducted, together with site visits. The results were used to provide the baseline for the SWOT analysis. Internal and external factors related to sustainable tourism were identified. The DPSIR framework was then employed. DPSIR begins with the driving forces (D) that interact with the environment. This results in pressure $(\mathrm{P})$ to balance the environment; the state of the environment (S) then changes accordingly. Finally, if a change goes beyond the carrying capacity of an ecosystem, an impact (I), which is a threat to humans, will be realized. Society must therefore invent tools that respond to or alleviate such impacts (R), restoring the balance. DPSIR is an integrated system that includes both human and natural systems, so adjustments in dynamic changes, adaptations, and transformations of various forms and dimensions can be expressed in a single format. However, there is a quantitative limitation, especially in the summing of different data types (Lewison et al., 2016). Therefore, to address this weakness, in this study we only employed the relationships among quantitative indicators. The detailed steps of the study are described below.

\subsection{Ecotourism stakeholder data collection}

Indicators related to the ecotourism activities of stakeholders were determined. Three questionnaires were designed, one for each of the three target groups: tourism-related operators, 
tourists, and members of the local communities. Basic personal details were collected for all groups. Specific questions varied. Questions for tourism-related operators included lodging patterns, utilities, tourist services supported, and environmental management. For tourists, the characteristics of their trips were recorded, including tourist activities, the number of people in a group, power and water demands, waste disposal behavior, expenditure on local products, and motivation. Notably, the attitudes toward ecotourism considered five factors, including natural resources, environmental attraction, environmental management, infrastructure, and costs during the trip. Questions for local communities related to basic information about their ways of life, the effects of ecotourism, and their relationship to ecotourism activities.

There were nine local operators who ran homestay businesses; all were interviewed. The tourist group included both overnight and day-trip tourists. Overnight tourists were interviewed, using the questionnaire, at their accommodation, while day trippers were interviewed at tourist spots. An appropriate sample size of tourists was calculated. The total number of tourists that visit Klong Kone per year was unknown; however, based on the equations of Cochran (1977) and Israel (1992), the number required for statistical confidence was at least 196, which was adjusted to 200 individuals.

In 2017, the local community had a population of 1381 people (Department of Local Administration 2017). The population size necessary for statistical confidence was at least 177.80, which was adjusted to 200 households, again based on the equations of Cochran (1977) and Israel (1992). The sample distribution was considered based on the condition and location of households in each village. This included the population who lived alongside the canal and those who were affected by tourism activities. Household interviews were conducted based on a random sampling technique.

Face-to-face interviews were conducted to administer the questionnaires to members of each target group. During data collection, the physical characteristics of business-related buildings and the nature of local community houses were also recorded to provide supplementary data concerning environmental and local area management.

In-depth interviews with local scholars and officers from the Administrative Organization were conducted. The interviews covered the history and culture of the area, the development of ecotourism in the area and how this affected local ways of life, and the environmental management of the area. According to Thai administration norms, these interviews involved staff from sub-district administration organizations and the village headmen (Department of Local Administration 2020). Sub-district officers have an official duty to encourage local people's participation in ecotourism activities. However, only those officers who were from local area were interviewed, and these results were included in the SWOT analysis. Many of the village headmen were involved in ecotourism activities, e.g., they owned resorts or restaurants. Hence, these group's data were included with tourismrelated operators.

\subsection{Data analysis}

The results of the questionnaire interviews were analyzed both qualitatively and quantitatively. Statistical analyses were performed using SPSS version 21.0 for Windows. One-way ANOVAs were computed to determine the mean values and standard deviations. Regarding the attitude of tourists as to whether they would visit again, the mean values of five indicator groups were ranked on a scale, from the highest (level 5) to the lowest (level 1). The re-visit and no re-visit responses of the indicators were determined by examining the 
statistical significance $(p<0.05)$. Results provided a baseline for the subsequent SWOT analysis and development of the DPSIR framework.

\subsection{Combining the SWOT analysis and the DPSIR framework}

A SWOT analysis and the DPSIR framework were used to explore the complexity of the groups involved. The SWOT results helped identify critical points, while the DPSIR framework was used to explore the ecotourism development lifecycle. Results from the questionnaire interviews, in-depth interviews with local wisdoms and officers of the sub-district administrative organization, site visits, and secondary-related data were classified into strengths or weaknesses, as internal factors of the area. This information was used to define the "state (S)" in the DPSIR framework of changes in the mangrove ecosystem.

External factors are those arising from laws and rules relating to an area, including environmental consequences from outside of the area, and used to identify opportunities and threats for subsequent use as "D", "P", "S", or "R".

The SWOT analysis allowed the determination of indicators in each dimension of DPSIR. Each indicator was divided into five levels, from insignificant to very high importance. For tourists, levels of consideration matched their levels of satisfaction. For the local public, their responses to closed questions determined their levels (Table 1). A moderate level was designed for open-ended questions that corresponded to each indicator. For the site visit, the results of observations and in-depth interviews were assigned level 3, in case the observations reflected the indicators listed.

The total scores for each indicator in the DPSIR framework were calculated; the response for each level indicated the level of importance of each indicator. Finally, a conceptual DPSIR model of ecotourism in mangrove areas was established. This model provided an understanding of the factors driving ecotourism activities that can cause pressure in mangrove areas, produce changes in the state and further impacts, and identify responses to control activities in mangrove areas.

Tourism innovations explored in this study focused on the achievement of sustainable aspects. These innovations were examined in a case-by-case manner, with the public interest sector as a key element and driver of tourism innovations (Hall, 2009). This can be addressed in multiple ways and with several methodological approaches (Jacob et al., 2003), including quantitative approaches to explore the issues unique to ecotourism and qualitative approaches to explore the sustainability of ecotourism (Hjalager, 2010). However, innovations in ecotourism are not episodic, but rather a continuous and ongoing process (Martin, 2004). Interestingly, Peeters et al., (2006) and Hall (2009) agreed that

Table 1 Score levels and the significance of indicators

\begin{tabular}{llll}
\hline Level & Importance & \multicolumn{2}{l}{ Stakeholders } \\
\cline { 3 - 4 } & & Local public & Tourists \\
\hline 5 & Very high importance & $80.01-100$ & $4.21-5.00$ \\
4 & High importance & $60.01-80.00$ & $3.41-4.20$ \\
3 & Moderate importance & $40.01-60.00$ & $2.61-3.40$ \\
2 & Slight importance & $20.01-40.00$ & $1.81-2.60$ \\
1 & Low importance & $0.01-20.00$ & $1.00-1.80$ \\
0 & Insignificant & No response & No response \\
\hline
\end{tabular}


current innovations in tourism pay attention to climate aspects. The innovative aspects of the present study are as follows: First, this study provided empirical evidence of ecotourism in mangrove areas that reflect the supply and demand in relation to various stakeholders. Second, the integration of SWOT and DPSIR was an aggregate innovation, in that they were used as a tool to explore the supply and demand of ecotourism and understand the importance of socioeconomic and environmental factors that can lead to sustainable outcomes. Third, the DPSIR ecotourism framework addressed the dynamic processes of the ecotourism life cycle, with regard to the carrying capacity of the area. This helped to explain the status of ecotourism in mangrove areas, using evidence from the study. Fourth, the policy and managerial strategies proposed in this study represent innovative ways to organize sustainable tourism and fulfill the socioeconomic and environmental components of ecotourism.

Overall, this study developed practical, evidence-based innovations, with a theoretical grounding, to create an ecotourism framework that included policy and managerial implications. These sustainable tourism strategies in mangrove areas represent a significant innovation in tourism, as proposed by Hjalager (1997) and Hall (2009).

\section{Results}

Here, the characteristics of ecotourism in the study area are outlined, to provide a background of the "eco-supply" required for ecotourism. The "eco-demand" in the area was determined from the responses of stakeholders engaged in ecotourism, together with the responses of members of the local communities. The SWOT analysis provided the internal and external factors that affect ecotourism. The indicators established in the DPSIR were analyzed and ranked to understand how ecotourism can support sustainable tourism in mangrove areas.

\subsection{Background of the case study}

The mangrove area selected for this study was Klong Kone, an outstanding ecotourism destination located in Samut Songkhram province, $75 \mathrm{~km}$ southwest of Bangkok, Thailand. The mangrove area covers 2920 hectares (Department of Marine and Coastal Resources 2018). Ecotourism in the study area was directly operated by local communities; specific activities varied depending upon the location of a village in relation to the sea (Fig. 2). According to Jaafar et al., (2014), ecotourism products reflect the unique features of a particular area. In Klong Kone, some villagers had formed career development groups based on their existing skills, e.g., sailing groups, cooking groups, ka-teng groups (involved in offshore cockle farms), prior to developing local ecotourism. The positive and negative impacts of ecotourism activities on the Klong Kone community are therefore unequal. Also, tourism levels vary by season, especially during low and high tides (Table 2). Year-round activities include sightseeing boat rides through the mangrove forests, ecology education, and feeding macaques (Macaca fascicularis), while mangrove planting is only possible between February and September. From March to April, the temperature is high and water levels decrease during the day, making the conditions suitable for mud skiing. Tourism activities can affect the supply and demand for ecosystem services. For example, Village No. 3 had the highest level of ecotourism activity. Different activities require both direct and indirect resources in different types of mangrove ecosystems. Direct 

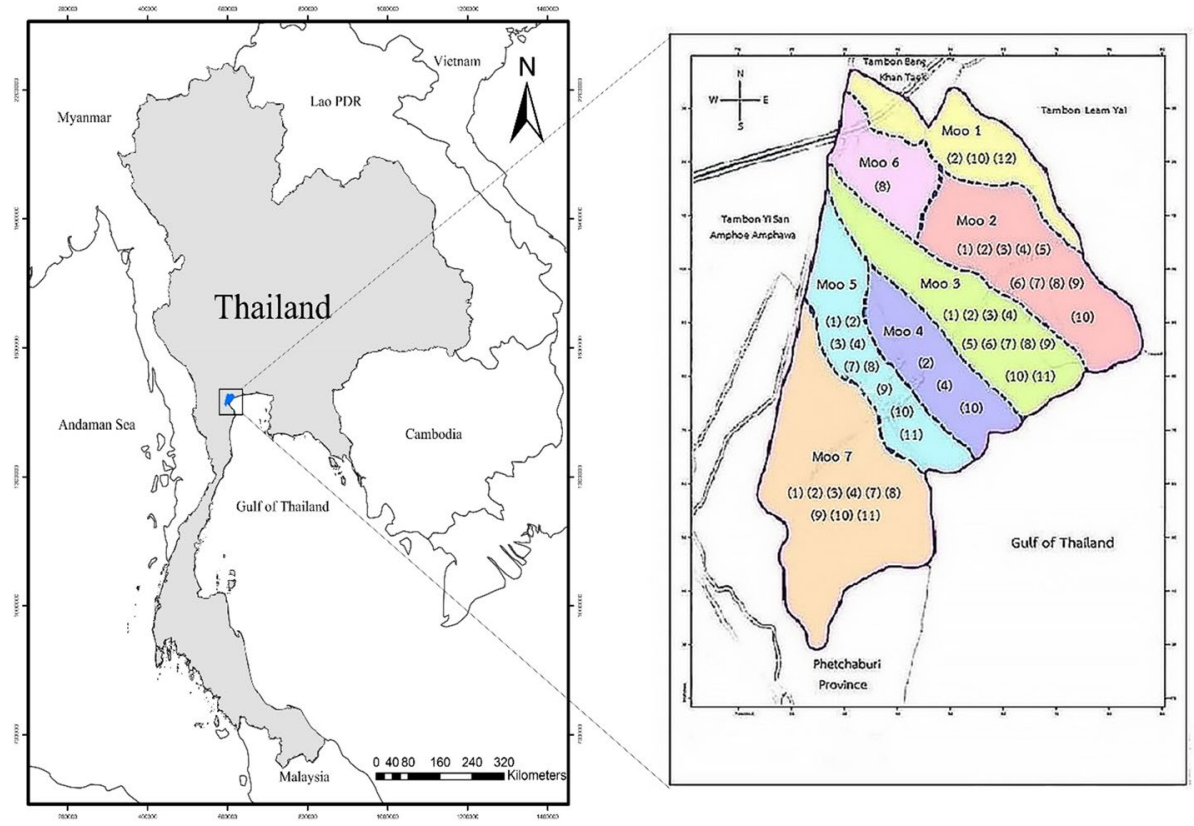

Fig. 2 Project location and boundaries of seven villages in the study area. Source: Based on a map supplied by Klong Kone Sub-district Administrative Organization. Note: Number indication in the brackets of each Moo (Thai's political region) illustrated ecotourism activities as described in Table 2

Table 2 Year-round timeline of ecotourism activities

\begin{tabular}{|c|c|c|c|c|c|c|c|c|c|c|c|c|}
\hline \multirow{2}{*}{ Ecotourism activity } & \multicolumn{12}{|c|}{ Month } \\
\hline & 1 & 2 & 3 & & 5 & 6 & & & 9 & 10 & 11 & 12 \\
\hline \multicolumn{13}{|l|}{ 1. Mangrove treeplanting } \\
\hline \multicolumn{13}{|l|}{ 2.Mangrove sightseeing and ecosystem education } \\
\hline \multicolumn{13}{|l|}{ 3. Sightseeing and feeding macaques } \\
\hline \multicolumn{13}{|l|}{ 4. Visiting cockle farms } \\
\hline \multicolumn{13}{|l|}{ 5. Sightseeing: krill traps along the coast } \\
\hline \multicolumn{13}{|l|}{ 6. Sightseeing: fishing formullet and catfish } \\
\hline \multicolumn{13}{|l|}{ 7. Dining and sightseeing of offshore shelters } \\
\hline \multicolumn{13}{|l|}{ 8.Dining: seafood } \\
\hline \multicolumn{13}{|l|}{ 9. Water skiing } \\
\hline \multicolumn{13}{|l|}{ 10. Mud skiingmud surfing to collect cockles } \\
\hline \multicolumn{13}{|l|}{ 11.Homestays/resorts } \\
\hline $\begin{array}{l}\text { 12. Watching demonstrations on how to make } \\
\text { coconut sugar }\end{array}$ & & & & & & & & & & & & \\
\hline
\end{tabular}


use comprises the loss of mangrove areas to make way for buildings, for purposes such as accommodation and utilities, while indirect use involves disturbance to habitats and pollution from ecotourism activities, especially water pollution.

Two key activities affected the internal structure of the ecosystem. First, the feeding of macaques changed their behavior. Previously, these monkeys fed on small animals, including crabs, among the mangroves. However, once feeding activities began, the macaques changed their food source and their numbers rapidly increased. The second activity involved problems with inappropriate mangrove planting activities. Most mangrove plants used for planting activities were Rhizophora apiculata, which cannot survive without preexisting first-order plants in the mangrove forest (Avicennia alba). When the planting activities ceased, there was no subsequent increase in forest area due to the lack of ongoing care and maintenance.

\subsection{Tourism operators}

There were nine local operators running homestays or resorts; these were mostly run as family businesses. Originally, the area was mainly residential, although some parts were developed from shrimp and/or cockle ponds. Some tourist homestays were built in mangrove areas, while shrimp ponds remain in some areas.

Most rooms (Fig. 3) are air-conditioned (77.8\%), with between one and ten rooms per resort, for one to three visitors per room. Tourist activities are operated directly by property owners.

The high season runs from November to February. Tourists generally visit during weekends, with most staying for 1 to 3 days. Tourists tend to arrive in groups, usually in private vehicles. The accommodation provides parking for 10 to 30 cars. Water is supplied by the Provincial Waterworks Authority, the same as for the local community. Tourist activities include mangrove planting, visiting shellfish farms, collecting cockles, feeding macaques, boat trips, and mud surfing.

Regarding environmental management, in situ wastewater treatment is installed to treat wastewater onsite. However, in some resorts, there is no obvious sewerage infrastructure.
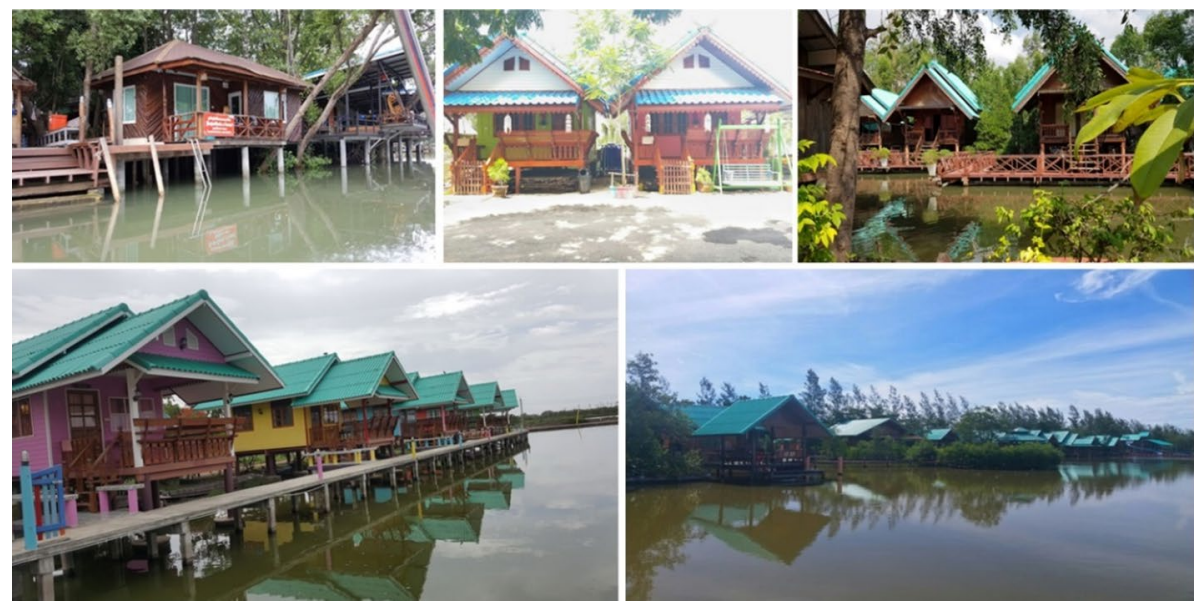

Fig. 3 Characteristics of the local accommodation 
For kitchen wastewater, there are grease traps and garbage traps. Treated effluent is released directly to natural water sources (Fig. 4). In the accommodation, garbage bins are provided inside and outside the rooms, but waste is not separated. Garbage collection is performed by local administrative organizations.

Demand for ecotourism activities led to invasion of the mangrove forests close to the accommodation locations. Some ecotourism activities have lacked an awareness of ecosystems, such as macaque feeding.

\subsection{Tourists}

The Klong Kone mangrove area is not far from Bangkok, and there is easy access from other tourist centers, resulting in the area generally receiving tourists on day trips or weekend tours (80.0\%). Per capita expenses are between 1000 and 2000 Thai baht (THB) per day, which is satisfactory for tourists, due to the area being located in an area where tourist expenditure is lower compared with the average tourist expenditure in Thailand, of THB 3646-4056 per person (Thailand National Statistical Office, 2019). When considering the seven categories of tourists' responses (Fig. 5), the highest level factors attractive to tourists were tourism costs, while those at a minor level were utilities, including water supply and electricity, clarity of signage, and sufficient accommodation and parking lots. This followed the change from the original mangrove forest area to a large number of restaurants, which was one of the main requirements of tourists apart from ecotourism. Shrimp paste, a famous local product that uses raw materials from mangrove forests, is also a tourist attraction. There were no negative responses regarding environmental quality and management of the area. However, the main problem is the aggregation of tourist attraction sites, i.e., restaurants, which results in traffic congestion.
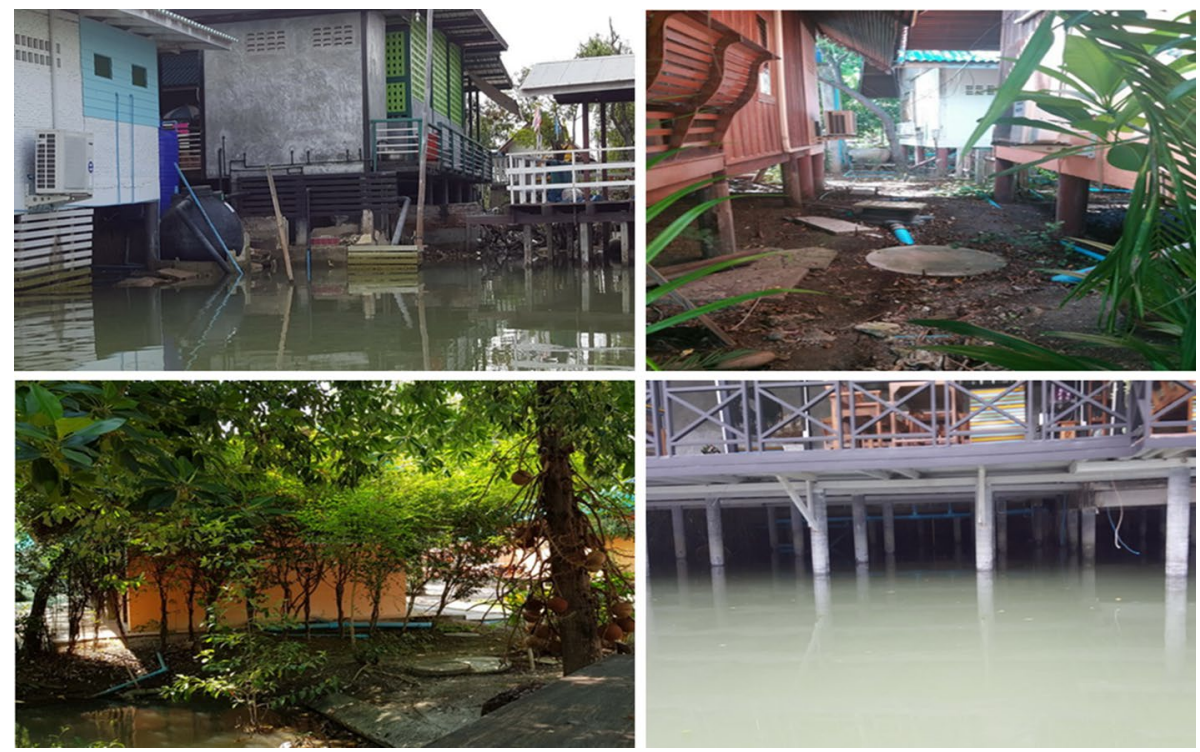

Fig. 4 Environmental management of the accommodation 


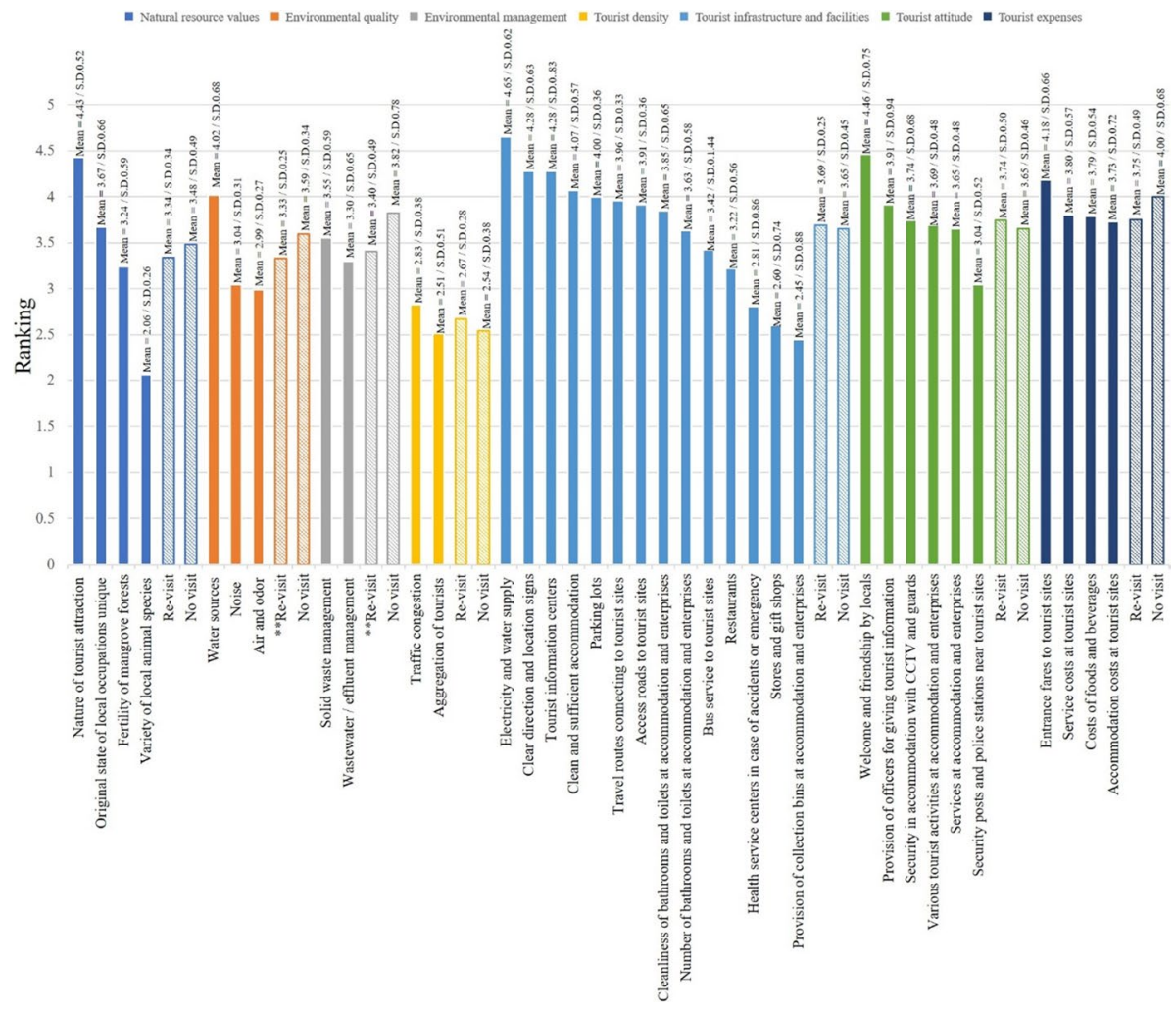

Fig. 5 Tourist responses toward ecotourism. Note $* *$ Correspondence is significant at $p<0.01$

The main activity of day-trip tourists was dining at restaurants. This activity generates both wastewater and solid waste. The primary problem is that these restaurants were built in the mangrove forests, another factor involving invasion and changes to the original area.

Tourists' responses regarding ecotourism resources in Klong Kone suggested the key factors that would significantly affect their revisiting the area $(p<0.01)$ were environmental quality and environmental management. No other factors were statistically significant. This reflects the need for good environmental conditions to encourage tourism in mangrove areas.

\subsection{Local community}

Most of the local Klong Kone population work in fishing or aquaculture (66.0\%). The average household income is THB 180,000 to 360,000 per year, which is close to the average household income of THB 323,357 per household per year in Thailand (Thailand National Statistical Office, 2019). For land holding, most villagers (85.5\%) had invaded mangrove areas for residential purposes. Once ecotourism took off in Klong Kone, $51 \%$ of interviewees stated they received benefits from tourism activities, e.g., selling local products or working in restaurants, while $46 \%$ reported negative environmental impacts, such as increased solid waste, sewage, air pollution, and noise, as well as social impacts, including 
overcrowding and changes in lifestyle (Fig. 6). They also reported both positive and negative economic impacts. Positive aspects included increased employment and income, while negative impacts included less fish and thus decreased income. Surprisingly, all local community members commented that they were affected by water quality changes, resulting from tourism activities, while this impact was not commented on by tourists. These findings reflected the actual impacts of tourism on the area.

\subsection{Assessment of internal and external factors}

A SWOT analysis was performed to assess sustainable ecotourism by considering both internal and external factors that affected ecotourism in mangrove areas (Fig. 7). The strengths of Klong Kone were its natural resources, which attracted tourists and related activities, while

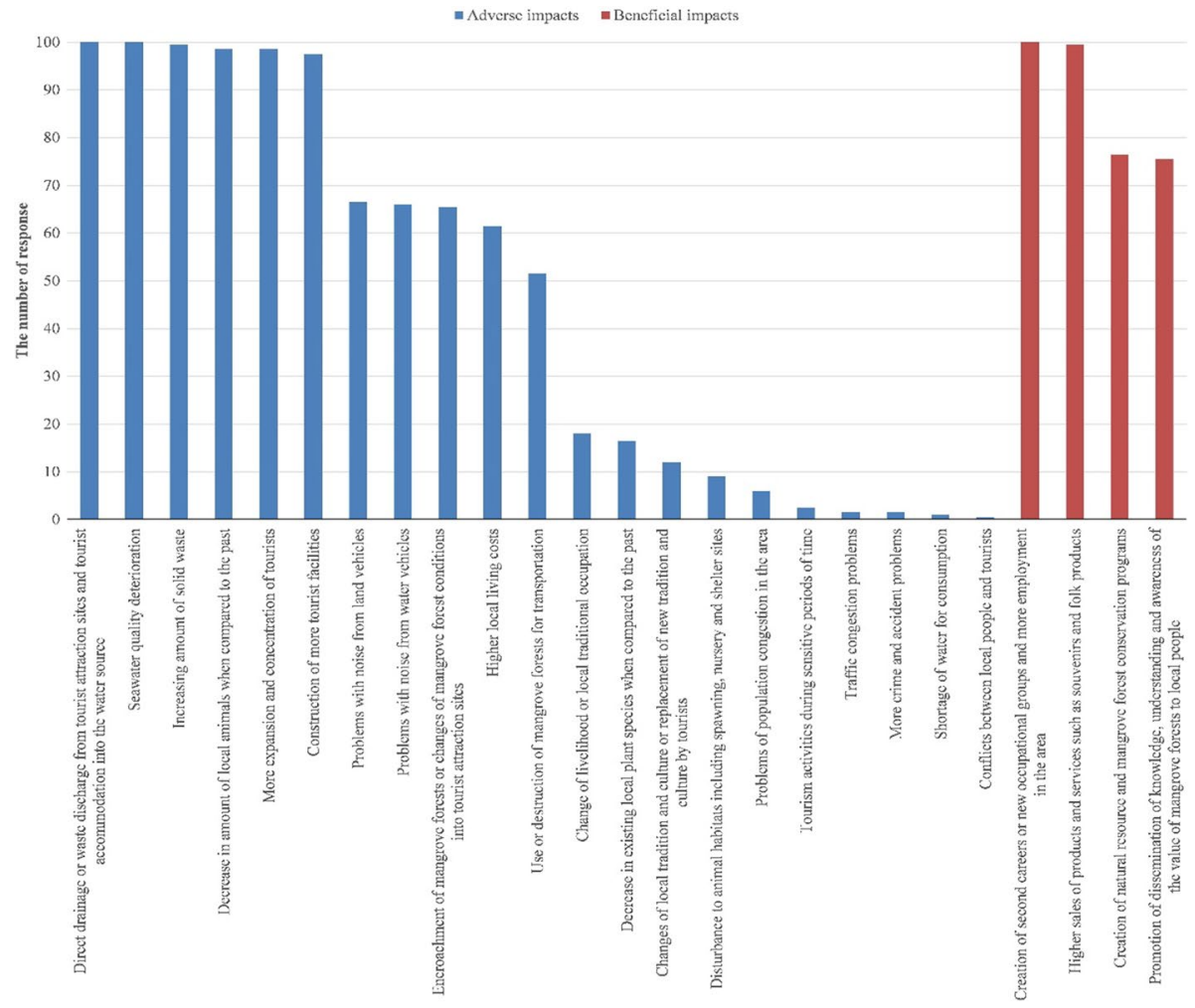

Fig. 6 Local community responses toward ecotourism. Remarks: impacts 


\subsection{Assessment of the DPSIR framework}

The DPSIR framework analysis included related sections from the questionnaires (evaluation of tourists' responses about ecotourism resources in Klong Kone, information on services provided to tourists in homestays, and impacts of ecotourism on the Klong Kone community). All data were combined with the data obtained from the in-depth interviews with local scholars and officers of Klong Kone Administrative Organization, as well as data from the site visits. Each indicator was prioritized into the DPSIR framework (Fig. 8); the highest scores of indicators for ecotourism driving forces (D) were ease of access, followed by promotion and public relations of tourist sites. The scores for natural resources in the area were of low importance because local entrepreneurs overlooked them and lacked awareness of their supply in ecosystems. For pressure (P), the key issue was pollution from tourism activities, especially water pollution, which consequently affected the state (S) and particularly changes in water quality. Factors related to natural resources reflected this, showing their importance for this aspect of the framework. However, the adequacy of basic public utilities received the highest score and was the top priority for both tourists and local communities. This indicated that both tourists and local communities focused on lifestyle benefits rather than the value of resources. Therefore, awareness building is of prime importance. For impacts (I), both positive and negative consequences were generated. The highest score was for land-use change, from mangrove forest to construction areas to support ecotourism activities. It was obvious that economic factors supported positive impacts, while the opposite reflected a higher cost of living. The weighting scores of factors in DPSIR affect the response (R), with a requirement for ecotourism activities to be maintained within the carrying capacity of a mangrove area.

The results of weighting the scores of the DPSIR indicators formed the analysis framework (Table 3). The driving forces that changed the mangrove forest began with tourism, including ease of access to the area, tourism promotion and public relations, and the variety of local tourism activities. These driving forces exerted pressure on Klong Kone's ecosystem services and other facilities. Increased tourists, tourism activities, and construction activities resulted in stakeholders, especially local tourism operators, seeking more ways to utilize natural resources and the environment. This resulted in increased pollution and

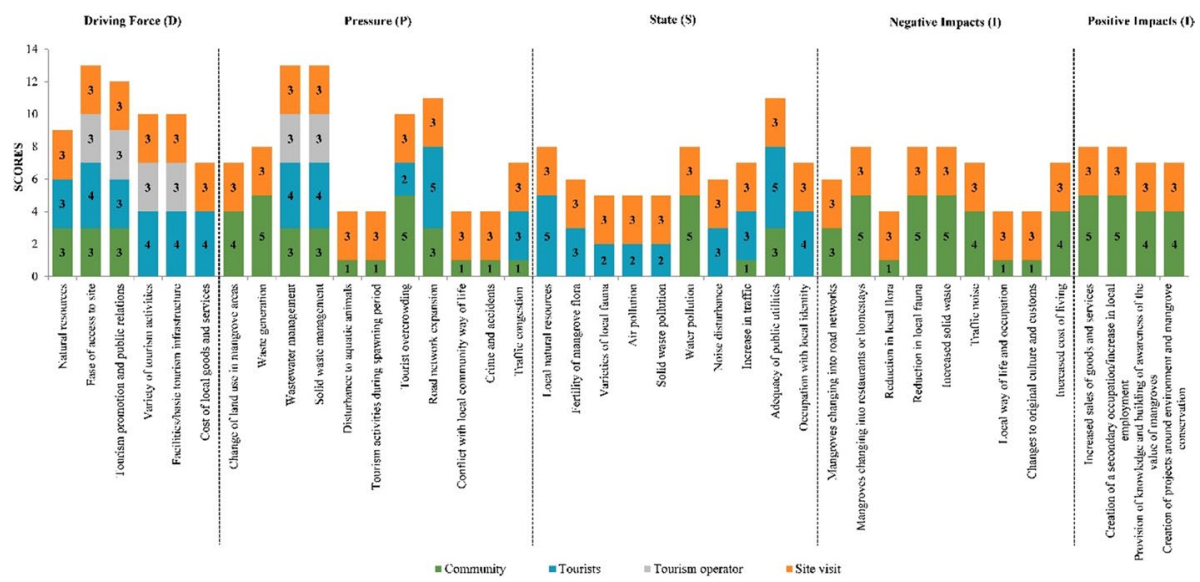

Fig. 8 Ranking of indicators using the DPSIR framework 


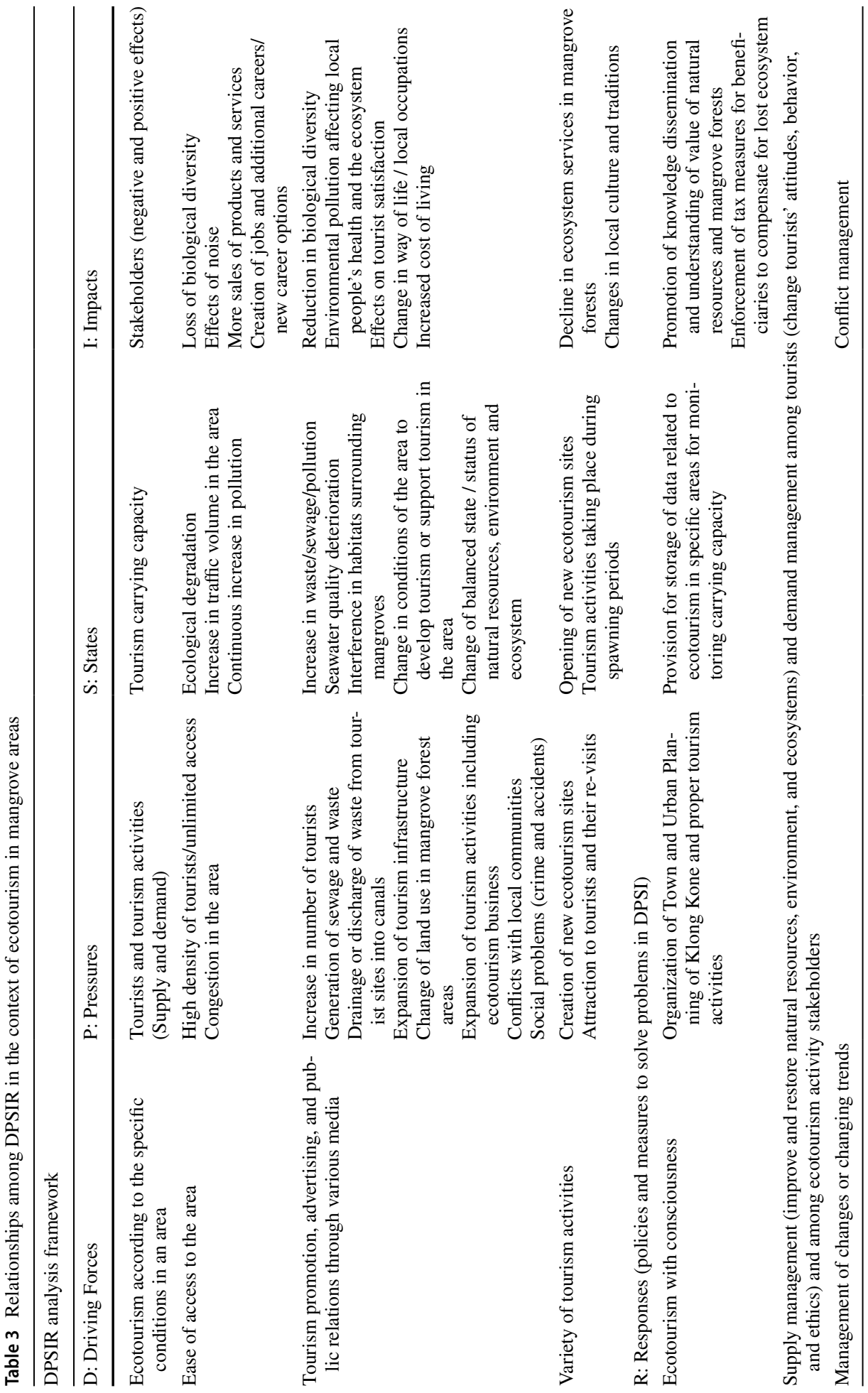


sewage, quantitatively and qualitatively changing the balance of the physical, chemical, and biological environment, probably resulting in violations of the relevant standards. The consequences were both positive and negative. A negative impact was the deterioration of mangrove areas, which both directly and indirectly affected local people and the ecosystem. It was noted during the survey that there were changes in benthic animal populations and the occurrence of plant diseases in the mangroves. Such issues have not previously been identified. To restore balance to mangrove areas, it is necessary to enforce policies to improve and restore natural resources and environments; this includes changing the attitudes and behavior of both tourists and stakeholders. Therefore, to develop an appropriate response $(\mathrm{R})$ in the form of policies and control measures, it is necessary to consider the first stage, the driving forces (D) that change with the ecotourism lifecycle. Emphasis should be placed on ecological awareness to ensure that ecotourists fully understand the value of mangrove forests. To address the pressures $(\mathrm{P})$, the Town and Urban Planning strategy for Klong Kone should be revised, with the scope for ecotourism activities established, and laws and regulations should be enforced. For the state (S), a database relating to ecotourism and the local conditions should be maintained, to monitor the carrying capacity and to assess any changes in the physical or ecological balance of the environment. The management of $\mathrm{D}, \mathrm{P}$, and $\mathrm{S}$ should involve proactive management of changes due to $\mathrm{I}$. However, if the situation reaches the impact level, a conflict may arise among those who gained and lost from such changes. The relationships among indicators from the DPSI steps could help to formulate the recommendations for a response, R. If the situation proceeded to the end, the impact would be more severe than the change management process. Therefore, such management should be considered as preventive action.

\section{Discussion}

First, we provide a discussion of the DPSIR conceptual framework of ecotourism. This is followed by a discussion of the policy and managerial implications of our analyses.

\subsection{DPSIR conceptual framework of ecotourism}

The DPSIR framework can be used to assess the status, trends, and sustainability of ecotourism and investigate the relationships between causes and effects of ecotourism according to particular conditions in a sensitive ecosystem such as mangrove forests (Bradley \& Yee, 2015; Tscherning et al., 2012). Development in areas of rich natural beauty may lead to socioeconomic benefits, but the loss of valuable resources must also be considered (Glyptou et al., 2012; Atun et al., 2019). According to ASEAN community-based tourism (CBT) standards (2016), ecotourism represents one type of CBT, as it seeks to empower communities to manage the growth of tourism and achieve community goals relating to well-being and economically, socially, and environmentally sustainable development. The results of the present study led to the development of a conceptual model of ecotourism in a mangrove area, based on the DPSIR framework and adapted from Kristensen (2004) (Fig. 9). The model was dynamic, based on the tourism lifecycle.

Based on the evolutionary period of Butler's tourism lifecycle concept (2006), the DPSIR framework can be used to conceptualize the key mechanisms driving tourism transformation and development into seven phases: exploration, involvement, development, consolidation, stagnation, decline, and rejuvenation. Ecotourism activities in our study area 


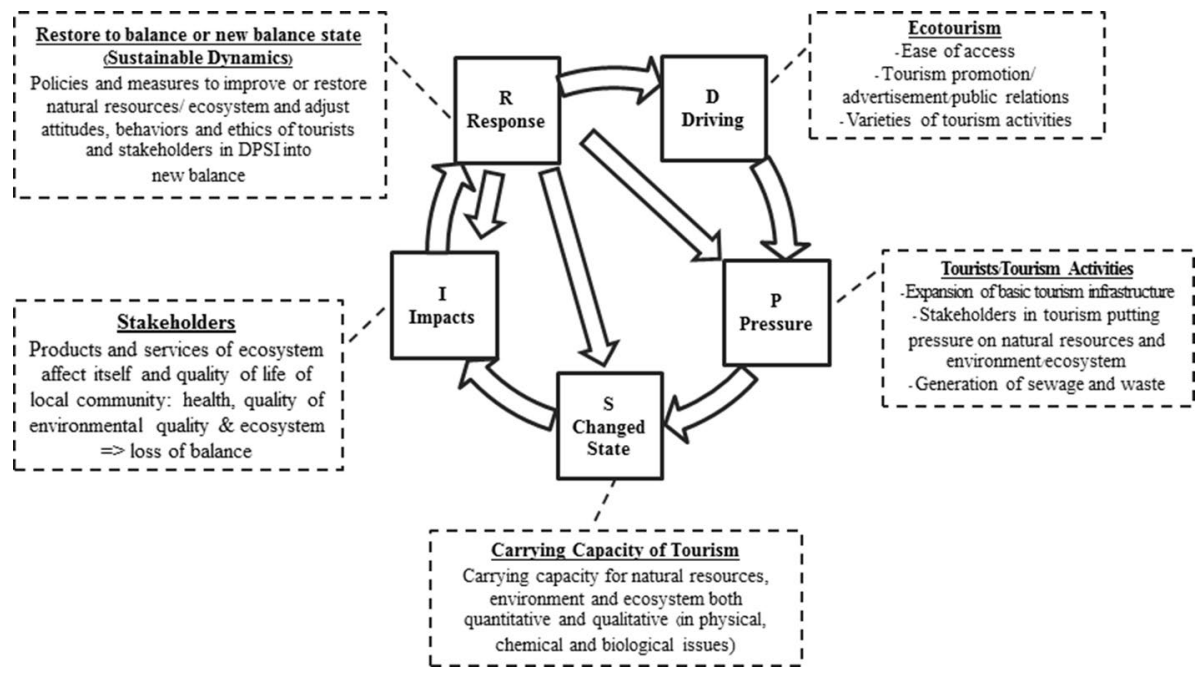

Fig. 9 DPSIR conceptual model of ecotourism in a mangrove area

were in the development phase. The ecotourism carrying capacity of Klong Kone is currently able to support the growing number of tourists. To support local tourism, it was crucial to focus on the knowledge and understanding of people in the local community, as well as continuous monitoring and evaluation of the carrying capacity of the ecosystem. However, the characteristics of ecotourism activities also adversely affected ecosystem itself. Therefore, if ecotourism in the mangrove area was allowed to proceed to the final stage of Butler's lifecycle (2006), there would be significant impacts on the mangrove ecosystem that would be difficult to restore.

\subsection{Policy and managerial implications}

If ecotourism in a mangrove area is a desired sustainable tourism target, policy and managerial strategies for how to achieve this should be developed based on evidence. The integration of a SWOT analysis and the DPSIR framework in this study provided an evidence-based assessment to describe the actual ecotourism conditions and the opinions of various stakeholders. The planning of any tourism development must consider relationships between local tourism activities and the local environment, as well as considering potential restrictions in the environmental, social (Reimer \& Walter, 2013), and economic dimensions (Spencer \& Nsiah, 2013) of the area. If there are no efforts made to manage the demand of ecotourism activities, the ability to maintain the supply of the mangrove ecosystem will be reduced.

At the policy level, the Thailand National Economic and Social Development Plan No.12 (2017-2021) stipulated the building of business services and potential tourism enterprises as one of the main policies. In this policy, the carrying capacity of an ecosystem and the ecotourism potential of an area are designated to achieve balance and sustainability. The strategies of tourism development, environmental and natural resource management, and public participation are also the main policies stipulated in the Thailand Local Development Plan (2018-2022). The concurrence of policy support at both a national and local level offers the chance to promote the balanced use of 
natural resources for ecotourism activities. The results of the present study could support the implementation of ecotourism while at the same time catering to the various demands of different groups and reducing the risks that threaten the supply of resources (see Fig. 7).

To explore the implications of our ecotourism case study, we used criteria adapted from the ASEAN CBT, which covers sustainable tourism targets (Butler, 1999). These targets include various dimensions, including environmental (targets 1 and 2), social (target 3), and economic dimensions (targets 4 and 5). The policy and managerial implications covered sustainable tourism targets and include important implications for stakeholders with regard to ecotourism in mangrove areas, as follows:

Target 1: Contribution to the conservation of natural resources.

The deterioration of mangrove forests and insufficient mangrove plantation were the main ecotourism activities that directly affected the mangrove ecosystem, especially benthic organisms, and increased the occurrence of plant diseases. This highlights the need for ecotourism operators to be given accurate information. Our survey found that attitudes and knowledge in relation to mangrove ecosystems differed among stakeholders, so these stakeholders were grouped according to their different managerial implications. The first group included local scholars and communities who possessed an excellent understanding of the area's nature and could share their knowledge with stakeholders engaged in ecotourism activities. The second group comprised stakeholders engaged in ecotourism activities. Individuals in this group exhibited various attitudes and knowledge around mangrove ecosystems, depending on their background and ecotourism activities, which led to their different impacts on mangrove ecosystems. For the latter group, appropriate communication should be employed to increase their understanding of the importance of mangrove conservation and that such conservation can indirectly increase the market value of their enterprises. Interconnections among various groups should be encouraged, for example, to transfer knowledge from local scholars to the younger generation. Promoting an awareness of the value of mangroves among government agencies is an important conservation managerial output revealed by this study.

Local government agencies could directly enforce rules to control mangrove encroachment. Remarkably, due to the current town and country planning regulations in Thailand, which support urban expansion, the conservation of mangrove areas, especially at the coastal zone, could be controlled by the Department of Marine and Coastal Resources. Importantly, sub-district administrative organizations have been directly empowered to control registered ecotourism activities.

Target 2: Contribution to improve the environment and mitigation of negative impacts.

The main environmental impacts in the study area came from restaurants and homestay activities. Measures to address these impacts should be both enforced and voluntary. Mitigation and monitoring measures are necessary, although such measures have never been conducted in this area. Measures to manage solid waste and control the discharge of wastewater are urgently required, as these impacts are directly emitted into the mangrove ecosystem. Legal enforcement could be enacted by the Provincial Office of Natural Resources and Environment, under the National Environmental Act (2018), for the implementation of mitigation and monitoring, and the sub-district administrative organization could control any activities in the area. 
Target 3: Contribution to social well-being, equitable distribution of benefits and costs, and valued cultural traditions.

The average income of the Klong Kone population is similar to that in the rest of Thailand. However, around half of the local population receive direct income benefits from ecotourism activities. In-kind benefits should be distributed throughout local communities. These include both public facilities, which should be sufficient for local people, and the right to live in a good environment, undisturbed by any ecotourism activities. Local cultural values, as shown by the schedule of ecotourism activities at each time of year (see Table 2), could serve to cater for both social preference and environmental recovery of the mangrove areas.

Community-based initiatives of rights to resources and owning and fostering collaboration and synergies within the local community are required to raise awareness about threats to mangrove forests.

Target 4: Tours and activities should be managed to ensure their quality.

Most ecotourism activities were conducted by local communities. The outstanding attractions include local wisdom and various seasonal activities. The main raw material for shrimp paste, the most famous local product, comes from mangrove areas. Demand for natural resources to support ecotourism activities and local products should be balanced with the supply ecosystem can provide. Knowledge about how to protect mangrove resources should be distributed to local heads of community, who can then directly communicate this knowledge to local people engaged in different ecotourism activities.

Target 5: Ensuring quality and services of homestays.

Tourists' responses related to the values that they benefit from. These include ecotourism activities, services, cleanliness, and facilities. Although tourists responded that good environmental management was a reason for revisiting the area, some survey results, especially with regard to wastewater treatment and waste management, were different. Environmental impacts should be an issue of concern. Sub-district administrative organizations have the power to control homestay operations under the Public Health Act (2007). In addition, awareness of environmental management among homestay operators should be increased, by stimulating market competition.

Important evidence to inform policy and managerial decisions arose from the DPSIR findings, as follows. First, at the policy level, adopting Town and Urban Planning measures to control and conserve mangrove areas was the most important factor. Second, the understanding and recognition of beneficial environmental impacts arising from ecotourism activities should be promoted among stakeholders. Third, both qualitative and quantitative monitoring of changes in mangrove ecosystems should be performed, with data stored in a locally maintained database. Public participation should be encouraged, to support sustainable tourism in a given area.

The impacts of lockdown measures in response to the COVID-19 crisis may have a negative impact on many tourism industries, but less so for ecotourism. This is because lockdown provides an opportunity for mangrove ecosystems to recover. This type of inkind benefit is crucial if sustainability targets are to be met in the long term. 


\section{Conclusion}

This study aimed to answer the question of whether ecotourism in mangrove areas conforms to sustainable tourism principles. First, sustainable tourism should optimize resource use and respect the sociocultural characteristics of local communities (Butler, 1999; Kiper, 2013; Niñerola et al., 2019; Zareba, 2017). The SWOT analysis we performed identified internal and external factors and how they drove the direction of sustainable tourism. The key strength of mangrove forests was that they were natural resources that attracted tourists to the area. Simultaneously, the weaknesses identified derived from the human exploitation of nature, as well as disturbances to and use of natural resources that resulted in ecosystem deterioration. The DPSIR ranking indicated that natural resources were a low-level driving force due to their lack of recognition by stakeholders. This led to pressures on the area.

Second, sustainable tourism should distribute any benefits among stakeholders (Jaafar and Maideen, 2012; ASEAN 2016; Kisi, 2019). Here, conflicts arose from the unequal distribution of benefits among local people, who gained economic income from ecotourism activities but lost their traditional ways of life. The responses of all groups reflected supply and demand in mangrove ecosystems, depending on the benefit they gained.

Third, sustainable tourism should protect the requirements of future generations (Blersch \& Kangas, 2013; ASEAN 2016; Horng et al., 2016). The results of our assessment indicated that there was a high level of pressure from development without conservation. Pressure from ecotourism activities also affected the carrying capacity of the study area. We found ecotourism was near the limit of the carrying capacity and was affecting the state of the local area. Importantly, we noted hidden impacts, including changes in benthic diversity and evidence of plant diseases. If ecotourism in this area continues in this way, it will not be sustainable tourism at all.

If any one of the above three aspects continues as currently, ecotourism in the mangrove area will become unsustainable. This will not only directly affect the ecotourism sector but also the entire mangrove ecosystem, ultimately resulting in negative socioeconomic impacts. A mechanism is required to manage conflicts and to reduce ecological, economic, and social losses associated with ecotourism. The results derived from our SWOT analysis and the DPSIR framework suggested this mechanism must operate via policy and managerial inputs.

Acknowledgements We wish to thank the interviewees that participated in this study, together with support from Department of Environmental Science, Silpakorn University, Thailand. We are grateful for the valuable comments from the anonymous reviewers.

\section{References}

Ahmad, F., Draz, M., Su, L., Ozturk, I., \& Rauf, A. (2018). Tourism and environmental pollution: Evidence from One Belt One Road Provinces of Western China. Sustainability, 10, 3520. https://doi.org/ $10.3390 /$ su 10103520

Arkwright, D., \& Kaomaneng, I.S. (2018). Mangrove ecotourism development on Kakaralamo Island North Halmahera: community perception, participation and development strategies. IOP Conference Series: Earth and Environmental. Science, 175, 012232., https://doi.org/10.1088/1755-1315/175/1012232

Atun, R. A., Nafa, H., \& Türker, Ö. O. (2019). Envisaging sustainable rural development through contextdependent tourism: a case of northern Cyprus. Environment, Development and Sustainability, 21, 1715-1744. https://doi.org/10.1007/s10668-018-0100-8 
Battisti, C., Poeta, C., \& Fanelli, G. (2016). An introduction to disturbance ecology: A road map for wildlife management and conservation. Springer.

Blersch, D. M., \& Kangas, P. C. (2013). A modeling analysis of the sustainability of ecotourism in Belize. Environment, Development and Sustainability, 15, 67-80. https://doi.org/10.1007/ s10668-012-9374-4

Bradley, P., \& Yee, S. (2015). Using the DPSIR Framework to develop a conceptual model: Technical support document. Resource document. Office of Research and Development, US Environmental Protection Agency. https://doi.org/10.13140/RG.2.1.1870.7608. Accessed 1 May 2019

Butler, R. W. (1999). Suatainable tourism: A state-of-the-art review. Tourism Geographies, 1(1), 7-25. https://doi.org/10.1080/14616689908721291

Butler, R.W. (2006). The origins of the tourism area life cycle. In R. Butler (Ed.), The tourism area life cycle (Vol. 1): Applications and modifications (pp.13-26). Clevedon: Channelview Publications.

Boyle, J. (1998). Cultural influences on implementing environmental impact assessment: insights from Thailand, Indonesia and Malaysia. Environmental Impact Assessment Review, 18, 95-116. https:// doi.org/10.1016/s0195-9255(97)00082-6

Chiu, Y.-T.H., Lee, W.-I., \& Chen, T.-H. (2014). Environmentally responsible behavior in ecotourism: Antecedents ad implications. Tourism Management, 40, 321-329. https://doi.org/10.1016/j.tourm an.2013.06.013

Chuang, Y. H., Yu, R. F., Chen, W. Y., Chen, H. W., \& Su, Y. T. (2018). Sustainable planning for a coastal wetland system with an integrated ANP and DPSIR model for conflict resolution. Wetland Ecology Management, 26(6), 1015-1036. https://doi.org/10.1007/s11273-018-9627-6

Cochran, W. G. (1977). Sampling Techniques (3rd ed.). John Wiley and Sons.

De Groot, R. S., Alkemade, R., Braat, L., Hein, L., \& Willemen, L. (2010). Challenges in integrating the concept of ecosystem services and values in landscape planning, management and decision making. Ecological Complexity, 7(3), 260-272. https://doi.org/10.1016/j.ecocom.2009.10.006

Department of Local Administration (2017). Population data. Resource document. Department of Local Administration. www.population.moe.go.th. Accessed 25 July 2019.

Department of Local Administration (2020). Administrative authority. Resource document. Department of Local Administration. www.population.moe.go.th. Accessed 19 January 2020.

Department of Marine and Coastal Resources (2018). Mangrove forest. Resource document. Department of Marine and Coastal Resources. https://www.dmcr.go.th. Accessed 25 July 2019.

Do, Y., Kim, S.-B., Kim, J. Y., \& Joo, G.-J. (2015). Wetland-based tourism in South Korea: who, when, and why. Wetland Ecology Management, 23(4), 779-787. https://doi.org/10.1007/ s11273-015-9418-2

Fattah, M., Utami, T. N., \& Intyas, C. A. (2020). Cost-benefit analysis of bee Jay Bakau resort probolinggo mangrove ecotourism management. Ecology, Environment and Conservation, 26, 570-575.

Gössling, S. (2002). Global environmental consequences of tourism. Global Environmental Change, 12, 283-302. https://doi.org/10.1016/s0959-3780(02)00044-4

Glyptou, K., Spilanis, I., Bourse, L., Le Tellier, J., Giraud, J.P., \& Legros, D. (2012). Sustainable tourism monitoring framework: Findings from a comparative study on Mediterranean Tourism destinations. Resource document. Organisation for Economic Co-operation and Development. http://www.congress. is/11thtourismstatisticsforum/papers/OECD_Sustainabletourism.pdf. Accessed 20 February 2018.

Hakim, L., Siswanto, D., \& Nakagoshi, N. (2017). Mangrove conservation in East Java: the ecotourism development perspectives. The Journal of Tropical Life Science, 7(3), 277-285. https://doi.org/10. $11594 /$ jtis.07.03.14

Hall, C. M. (2009). Innovation and tourism policy in Australia and New Zealand: never the twain shall meet? Journal of Policy Research in Tourism, Leisure and Events, 1(1), 2-18. https://doi.org/10. 1080/19407960802703466

Hjalager, A. M. (1997). Innovation patterns in sustainable tourism-an analytical typology. Tourism Management, 6, 197-224. https://doi.org/10.1016/s0261-5177(96)00096-9

Hjalager, A. M. (2010). A review of innovation research in tourism. Tourism Management, 31, 1-12. https://doi.org/10.1016/j.tourman.2009.08.012

Hastuti, T.K., \& Yuliati, U. (2017) A model for mangrove forest management based on community empowerment in Bantul Regency. Journal of Environmental Management and Tourism, 6(22), 1232-1237. https://doi.org/10.14505//jemt.V8.6(22).10

Hearne, R. R., \& Santos, C. A. (2005). Tourists' and lacals' preferences toward ecotourism development in the Maya biosphere reserve, Guatemala. Environment, Development and Sustainability, 7 , 303-318. https://doi.org/10.1007/s10668-004-2944-3 
Hirotsune, K. (2011). Tourism, sustainable tourism and ecotourism in developing countries. Resource document. Proceedings of the ANDA International Conference. https://www2.gsid.nagoya-u.ac.jp/ blog/anda/files/2011/08/4-kimura_hirotsunee38080.pdf. Accessed 20 February 2018.

Hitchner, S. L., Apu, F. L., Tarawe, L., Sinah, S. G., Aran, N., \& Yesaya, E. (2009). Community-based transboundary ecotourism in the Heart of Borneo: a case study of the Kelabit Highlands of Malaysia and the Kerayan Highlands of Indonesia. Journal of Ecotourism, 8(2), 193-213. https://doi.org/ $10.1080 / 14724040802696064$

Hoang, H. T. T., Truong, Q. H., Nguyen, A. T., \& Hens, L. (2018). Multiple criteria evaluation of tourism potential in the Central Highlands of Vietnam: Combining Geographic Information System (GIS). Sustainability. https://doi.org/10.3390/su1003097

Horng, J.-S., Wang, C.-J., Liu, C.-H., Chou, S.-F., \& Tsai, C.-Y. (2016). The role of sustainability service innovation in crafting the vision of the hospitality industry. Sustainability, 8, 223. https://doi. org/10.3390/su8030223

Idajati, H., Pamungkas, A., \& Kukinul, V. S. (2016). The level of participation in mangrove ecotourism development, Wonorejo Surabaya. Procedia Social and Behavioral Sciences, 227, 515-520. https:// doi.org/10.1016/j.sbspro.2016.06.109

Israel, G. D. (1992). Sampling the evidence of extension program impact. IFAS.

Jaafar, M., \& Maideen, S. A. (2012). Ecotourism-related products and activities, and the economic sustainability of small and medium island chalets. Tourism Management, 33, 683-691. https://doi.org/ 10.1016/j.tourman.2011.07.011

Jaafar, M., Nordin, A. O. S., Abdullah, S., \& Marzuki, A. (2014). Geopark ecotourism product development: a study on tourist differences. Asian Social Sciences, 10(11), 42-55. https://doi.org/10.5539/ ass.v10n11p42

Jacob, M., Tintoré, J., Aguiló, E., Bravo, A., \& Mulet, J. (2003). Innovation in the tourism sector: results from a pilot study in the Balearic Islands. Tourism Economics, 9(3), 279-295. https://doi.org/10. $1177 / 135481660300900303$

Kazemi, F., Abolhassani, L., Rahmati, E. A., \& Sayyad-Amin, P. (2018). Strategic planning for cultivation of fruit trees and shrubs in urban landscapes using SWOT method: A case study for the city of Mashhad, Iran. Land Use Policy, 70, 1-9. https://doi.org/10.1016/j.landusepol.2017.10.006

Kiper, T. (2013). Role of ecotourism in sustainable development. In M. Ozyavuz, (Ed.), Advances in landscape architecture. IntechOpen. Doi: https://doi.org/10.5772/55749

Kisi, N. (2019). A strategic approach to sustainable tourism development using the A'WOT hybrid method: A case study of Zonguldak. Sustainability. https://doi.org/10.3390/su11040964

Koens, J. F., Dieperink, C., \& Miranda, M. (2009). Ecotourism as a development strategy: experiences from Costa Rica. Environment, Development and Sustainability, 11, 1225-1237. https://doi.org/10. 1007/s10668-009-9214-3

Kristensen, P. (2004). The DPSIR framework. Resource document. United Nations Environment Programme. https://www.ifremer.fr/dce/content/download/69291/913220/file/DPSIR.pdf. Accessed 1 February 2018.

Lewison, R. L., Rudd, M. A., Al-Hayek, W., Baldwin, C., Beger, M., Lieske, S. N., Jones, C., Satumanatpan, S., Junchompoo, C., \& Hines, E. (2016). How the DPSIR framework can be used for structuring problems and facilitating empirical research in coastal systems. Environmental Science \& Policy, 56, 110-119. https://doi.org/10.1016/j.envsci.2015.11.001

Ly, T.P., \& Bauer, T. (2014). Ecotourism in mainland Southeast Asia: Theory and practice. Tourism, Leisure and Global Change, 1(1), 61-80. https://creativecommons.org/licences/

Martin, L. M. (2004). E-innovation: internet impacts on small UK hospitality firms. International Journal of Contemporary Hospitality Management, 16(2), 82-90. https://doi.org/10.1108/0959611041 0519964

May, V. (1991). Tourism, environment and development: Values, sustainability and stewardship. Tourism Management, 12(2), 112-118. https://doi.org/10.1016/0261-5177(91)90065-2

Mimidis, K., Andrikakou, P., Kallioras, A., \& Pliakas, F. (2017). The DPSIR approach to groundwater management for sustainable development in coastal areas: The case of Nea Peramos aquifer system, Kalava, Greece. Water Utility Journal, 16, 67-80.

Niñerola, A., Sánchez-Rebull, M.-V., \& Hernández-Lara, A.-B. (2019). Tourism research on sustainability: A bibliometric analysis. Sustainability, 11, 1377. https://doi.org/10.3390/su11051377

Oh, K., Jeong, Y., Lee, D., \& Lee, W. (2002). An integrated framework for the assessment of urban carrying capacity. Journal of Korea Planning Association, 37(5), 7-26. https://www.researchgate.net/publi cation/285756441_An_integrated_framework_for_the_assessment_of_urban_carrying_capacity

Peeters, P., Gössling, S., \& Becken, S. (2006). Innovation towards tourism sustainability: climate change and aviation. International Journal of Innovation and Sustainable Development, 1(3), 184-200. 
Pornprasit, P., \& Rurkkhum, S. (2017). Performance evaluation of community-based ecotourism: a case study in Satun province, Thailand. Journal of Ecotourism, 18, 42-59.

Purba, R. B., Aulia, F., Dwilita, H., \& Nadra, U. (2018). Increasing income for communities in Lubuk Kertang Village through village-based business enterprises (BUMDES) based on mangrove ecotourism. International Journal of Economics, Commerce and Management, 11, 629-636.

Rahman, K.M., Rakhimov, I.I., \& Khan, M.N.H. (2017). Activity budgets and dietary investigations of Varanus salvator Reptilia: Varanidae) in Karamjal ecotourism spot of Bangladesh Sundarbans mangrove forest. Basic and Applied Herpetology, 31, 45-56. https://doi.org/10.11160/bah.79

Rahmila, Y.I., \& Halim, M.R. (2018). Mangrove forest development determined for ecotourism in Mangunharjo Village Semarang. E3S Web of Conferences, 73, 04010.

Reimer, J. K., \& Walter, P. (2013). How do you know it when you see it? Community-based ecotourism in the Cardamom mountains of southwestern Cambodia. Tourism Management, 34, 122-132. https://doi. org/10.1016/j.tourman.2012.04.002

Ross, S., \& Wall, G. (1999). Evaluating ecotourism: The case of North Sulawesi Indonesia. Tourism Management, 20(6), 673-682. https://doi.org/10.1016/S0261-5177(99)00044-0

Sahani, N. (2019). Application of analytical hierarchy process and GIS for ecotourism potentiality mapping in Kullu District. Environment, Development and Sustainability. https://doi.org/10.1007/ s10668-019-00470-w

Satyanarayana, B., Bhanderi, P., Debry, M., Maniatis, D., Foré, F., Badgie, D., Jammeh, K., Vanwing, T., Farcy, C., Koedam, N., \& Dahdouu-Guebas, F. (2012). A socio-ecological assessment aiming at improved forest resource management and sustainable ecotourism development in the mangroves of Tanbi Wetland National Park, The Gambia, West Africa. AMBIO, 41(5), 513-526. https://doi.org/10. 1007/s 13280-012-0248-7

Saveriades, A. (2000). Establishing the social tourism carrying capacity for the tourist resorts of the east coast of the Republic of Cyprus. Tourism Management, 21(2), 147-156. https://doi.org/10.1016/ S0261-5177(99)00044-8

Situmorang, R.O.P. (2018). Social capital in managing mangrove ecotourism area by the Muara Baimbai community. Indonesian Journal of Forestry Research, 5(1), 21-34. https://doi.org/10.20886/ijfr. 2018.5.1.21-34.

Skrondas, N.A., \& Karavitis, C.A. (2015). Evaluation and comparison of DPSIR framework and the combined SWOT-DPSIR analysis (CSDA) approach: towards embracing complexity. GlobalNEST , 17(1), 198-209. https://doi.org/10.30955/gnj.001480

Spencer, D. M., \& Nsiah, C. (2013). The economic consequences of community support for tourism: A case study of a heritage fish hatchery. Tourism Management, 34, 221-230. https://doi.org/10.1016/j.tourm an.2012.04.003

Teka, O., Houessou, L. G., Djossa, B. A., Bachmann, Y., Oumorou, M., \& Sinsin, B. (2019). Mangroves in Benin, West Africa: threats, uses and conservation opportunities. Environment, Development and Sustainability, 21(3), 1153-1169. https://doi.org/10.1007/s10668-017-0075-x

Thailand National Statistical Office (2019). Revenue and Household Expenditure Branch. Resource document. Thailand National Statistical Office. www.Statbbi.nso.go.th/staticreport/page/sector/en/08.aspx. Accessed 1 April 2019.

The Association of Southeast Asian Nations (2016). ASEAN community based tourism standard. www. asean.org. Accessed 25 December 2020

Treephan, P., Visuthismajarn, P., \& Isaramalai, S-A. (2019). A model of participatory community-based ecotourism and mangrove forest conservation in Ban Hua Thang, Thailand. African Journal of Hospitality, Tourism and Leisure, 8(5).

Tsai, H.-T., Tzeng, S.-Y., Fu, H.-H., \& Wu, J.C.-T. (2009). Managing multinational sustainable development in the European Union based on the DPSIR framework. African Journal of Business Management, 3(11), 727-735.

Tscherning, K., Helming, K., Krippner, B., Sieber, S., \& Paloma, S. G. (2012). Does research applying the DPSIR framework support decision making? Land Use Policy, 29, 102-110. https://doi.org/10.1016/j. landusepol.2011.05.009

Tseng, M.-L., Lin, C., Remen Lin, C.-W., Wu, K.-J., \& Sriphon, T. (2019). Ecotourism development in Thailand: Community participation leads to the value of attraction using linguistic preferences. Journal of Cleaner Production, 231, 1319-1329. https://doi.org/10.1016/j.clepro.2019.05.305

Vidal-Abarca, M., Suárez-Alonso, M., Santos-Martín, F., Martín-López, B., Benayas, J., \& Montes, C. (2014). Understanding complex links between fluvial ecosystems and social indicators in Spain: an ecosystem services approach. Ecological Complexity, 20, 1-10. https://doi.org/10.1016/j.ecocom. 2014.07.002 
Wuelser, G., \& Pohl, C. (2016). How researchers frame scientific contributions to sustainable development: a typology based on grounded theory. Sustainability Science, 11, 789-800. https://doi.org/10.1007/ s1162501603637

Yacob, M..F., Jaafar, M., \& Marzuki, A. (2013). Promotion ecotourism product development in Kilim Geopark based on tourists'perceptions. Resource document. Proceedings of International Conference on Tourism Development. https://core.ac.uk/download/pdf/83543879.pdf. Accessed 28 January 2020.

Yan, L., Gao, B. W., \& Zhang, M. (2017). A mathematical model for tourism potential assessment. Tourism Management, 63, 355-365. https://doi.org/10.1016/j.tourman.2017.07.003

Zareba, D. (2017). Tourism caught in a trap-background of sustainable tourism and ecotourism. Resource document. Atitlan EKOTURYSTYKA. http://atitlan.pl/en/background-of-ecotourism/. Accessed 4 March 2018.

Zhuang, H., Lassoie, J. P., \& Wolf, S. A. (2011). Ecotourism development in China: prospects for expanded roles for non-governmental organisations. Journal of Ecotourism, 10(1), 46-63. https://doi.org/10. $1080 / 14724041003686813$

Publisher's Note Springer Nature remains neutral with regard to jurisdictional claims in published maps and institutional affiliations. 